\title{
Application of 2D morphological model to assess the response of Karnafuli River due to capital dredging
}

\author{
Sarfaraz Alam*, M. Abdul Matin \\ Department of Water Resources Engineering, Bangladesh University of Engineering and Technology, Dhaka, Bangladesh
}

Email address:

sarfaraz@wre.buet.ac.bd(S. Alam)

\section{To cite this article:}

Sarfaraz Alam, M. Abdul Matin. Application of 2D Morphological Model to Assess the Response of Karnafuli River due to Capital Dredging. Journal of Water Resources and Ocean Science. Vol. 2, No. 3, 2013, pp. 40-48. doi: 10.11648/j.wros.20130203.13

\begin{abstract}
The major sea port of Bangladesh is the Chittagong port located on the right bank of Karnafuli river of Bangladesh. This river port is considered as the lifeline of the economic activities of the country due to its increasing trade demand. Many port facilities have been planned to be implemented in future to meet this increasing demand. Due to manmade interventions the river flow becomes interrupted and thereby may cause the change in river morphology. Recently Chittagong Port Authority (CPA) has undertaken $3.5 \mathrm{Mm}^{3}$ Capital Dredging and $2.5 \mathrm{~km}$ long bank protection initiative from 3rd Karnafuli bridge to Sadarghat jetty. This study focuses mainly on the application of 2D mathematical model to assess the response of the river due to such development works on Karnafuli River. Necessary data have been collected from CPA and the model was set using the bathymetry of 2009. The river reach between Kalurghat and Khal no-18 has been selected for the study purpose. Time series discharge and water level data were used as boundary condition at upstream and downstream consecutively. Calibration and validation have been carried out with the recent water level data at Sadarghat and Khal no-10. After hydrodynamic calibration and validation the model was adjusted to match the change in bed level with the observed data. Different hydrodynamic and morphological assessments like variation of velocity, sediment transport and bed level changes have also been studied. It was further used to assess the effect of Capital dredging and Bank Protection near Sadarghat area. Model result shows slight increase in velocity and sediment transport due to project implementation. It also changes the rate of erosion/ deposition at some location of the selected reach. It is hoped that the results of the model simulation will be helpful to suggest the effect of possible future development work to be implemented on this river.
\end{abstract}

Keywords: Karnafuli River, Chittagong Port, Capital dredging, Morphodynamics, 2D Modeling

\section{Introduction}

Karnafuli river, which is the major river of Chittagong, originates from Lushai hills in Mizoram state and flows about $270 \mathrm{~km}$ south and southwest through the southeastern part of Bangladesh to reach the Bay of Bengal. During this course this meandering river passes Kaptai hydroelectric power plant, Halda-Karnafuli confluence and several bridges (Fig. 1).

The length of the river from Kaptai Dam to Halda-Karnafui confluence is about $45 \mathrm{~km}$ and from Halda-Karnafuli confluence to BN Academy is about $30 \mathrm{~km}$. Karnafuli river is a tidal river having semi-diurnal characteristics. During flood period the flow travels long distance in the upstream direction of Halda river and very near to Kaptai Dam in upper Karnafuli river. This study mainly focuses on the lower part of Karnafuli river spanning from Kalurghat to Khal no-18. Lower Karnafuli river is the most important portion of the whole river due to the vast economic activities. Regular maintenance of this portion of river is necessary to keep it navigable for safe transportation of vessels. Recently capital dredging work at Sadarghat area is running to maintain sufficient draft. Thus the application of a 2D mathematical model to assess the effect of capital dredging at this location is highly envisaged.

A 2D model Delft3D has been applied to simulate the hydrodynamic and morphological processes of Karnafuli river. Delft3D consists of different modules such as Flow, MOR, Wave, WAQ. For this study the Flow module is used which is a multidimensional (2D or $3 \mathrm{D})$ hydrodynamic and transport simulation program. This module is capable of calculating unsteady flow and transport phenomena resulting from tidal and meteorological forcing on curvilinear grid. It is also possible to take into consideration some other parameters such as temperature, salinity and different constituents and observe the $2 \mathrm{D}$ or $3 \mathrm{D}$ distribution 
of the results. To know and predict the navigability and erosion/deposition pattern it is important to know the hydrodynamic and morphological characteristics of the river which is reflected by its flow velocity, shear stress and sediment transport. Earlier in 1987, Department of Water Resources Engineering (WRE), Bangladesh University of Engineering and Technology (BUET) developed a mathematical model study to assess the $1 \mathrm{D}$ hydrodynamics of this river [5]. In 1990, Danish Hydraulic Institute (DHI) and BUET applied a 2D model MIKE 21 at the entrance of Karnafuli river [7, 8]. Recently Chittagong Port Authority (CPA) and WRE of BUET had used a quasi 2D model to assess the effect of $3^{\text {rd }}$ Karnafuly bridge on the navigability of this river within the port limit $[1,2]$. They also conducted a study to assess the effect of RCC jetty construction near Sadarghat area in 2010 [3]. The present research mainly deals with the hydro-morphological analysis using well known Delft3D morphological model.

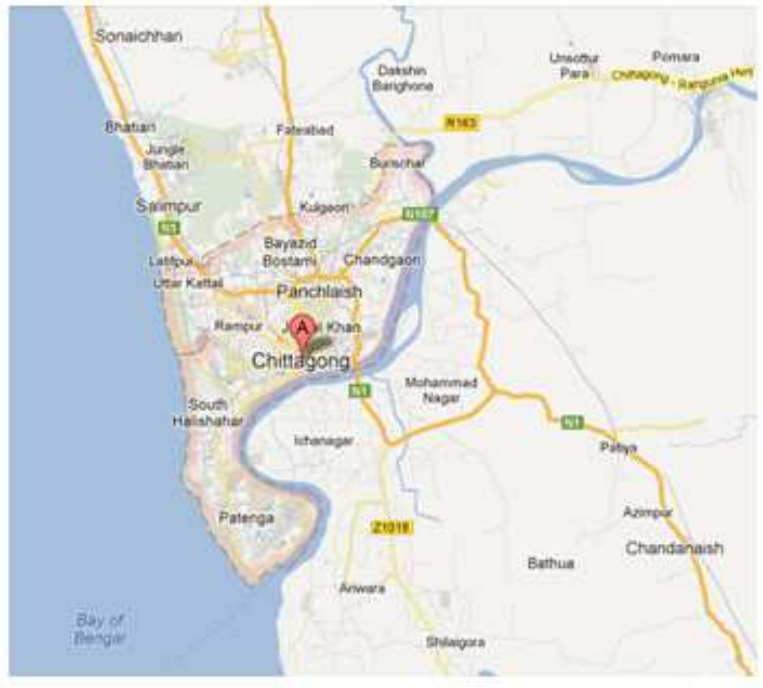

(a)

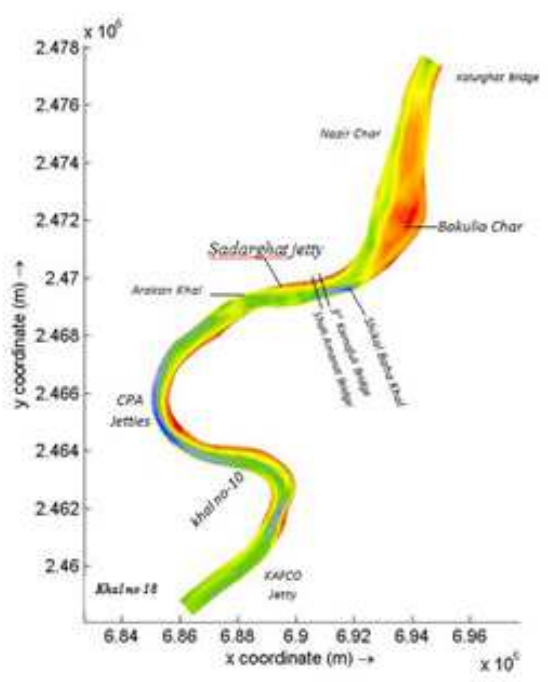

(b)

Figure 1. (a) Karnafuli river in Chittagong (source: Google) (b) Plan view of Karnafuli River

\section{Model Description}

Delft3D solves horizontal momentum, continuity and transport equation for hydrodynamic simulation. It solves Navier-Stokes equation for an incompressible fluid. The FLOW manual [6] of Delft3D extensively describes all the

$$
\begin{gathered}
\frac{\partial u}{\partial x}+\frac{\partial v}{\partial y}+\frac{\partial w}{\partial z}=0 \\
\frac{\partial v}{\partial t}+\frac{\partial v u}{\partial x}+\frac{\partial v^{2}}{\partial y}+\frac{\partial v w}{\partial z}+f u+\frac{1}{\rho_{0}} P_{y}-F_{y}-\frac{\partial}{\partial z}\left(v_{v} \frac{\partial v}{\partial z}\right)=0 \\
\frac{\partial u}{\partial t}+\frac{\partial u^{2}}{\partial x}+\frac{\partial u v}{\partial y}+\frac{\partial u w}{\partial z}-f v+\frac{1}{\rho_{0}} P_{x}-F_{x}-\frac{\partial}{\partial z}\left(v_{v} \frac{\partial u}{\partial z}\right)=0
\end{gathered}
$$

parameters and equations used in Delft3d-Flow module. Continuity (Eq. 1) and momentum equations (Eq.2-3) are shown which are to be solved by the model [10] for computation of velocities. Here $\mathrm{u}, \mathrm{v}$ and $\mathrm{w}$ define the velocity components in three perpendicular directions and $\mathrm{v}_{\mathrm{H}}, \mathrm{v}_{\mathrm{v}}$ are the horizontal and vertical eddy viscosity, $f_{\mathrm{u}}, f_{\mathrm{v}}$ are coriolis paremeters which are neglected in this case. Horizontal pressure terms $\mathrm{P}_{\mathrm{x}}$ and $\mathrm{P}_{\mathrm{y}}$ for a certain depth $\mathrm{z}$ can be determined by (Boussinesq approximations) using Eq. (4 and 5) where $\zeta, \rho, \rho_{0}$ and $g$ denote water level elevation, density, reference density of water and gravitational acceleration. The horizontal friction terms $F_{x}$ and $F_{y}$ (Reynold's stresses) are determined using the eddy viscosity concept. (Eq. 6 and 7).

$$
\begin{gathered}
\frac{1}{\rho_{0}} P_{x}=g \frac{\partial \zeta}{\partial x}+\frac{g}{\rho_{0}} \int_{z}^{\zeta}\left(\frac{\partial \rho}{\partial x}+\frac{\partial z^{\prime}}{\partial x} \frac{\partial \rho}{\partial z^{\prime}}\right) d z^{\prime} \\
\frac{1}{\rho_{0}} P_{y}=g \frac{\partial \zeta}{\partial y}+\frac{g}{\rho_{0}} \int_{z}^{\zeta}\left(\frac{\partial \rho}{\partial y}+\frac{\partial z^{\prime}}{\partial y} \frac{\partial \rho}{\partial z^{\prime}}\right) d z^{\prime} \\
F_{x}=\frac{\partial}{\partial x}\left(2 v_{H} \frac{\partial u}{\partial x}\right)+\frac{\partial}{\partial y}\left(v_{H}\left(\frac{\partial u}{\partial y}+\frac{\partial v}{\partial x}\right)\right) \\
F_{y}=\frac{\partial}{\partial y}\left(2 v_{H} \frac{\partial v}{\partial y}\right)+\frac{\partial}{\partial x}\left(v_{H}\left(\frac{\partial u}{\partial y}+\frac{\partial v}{\partial x}\right)\right)
\end{gathered}
$$

The advection-diffusion equation [12] is also shown in $\mathrm{Eq}(8)$.

$$
\begin{aligned}
& \frac{\partial[h c]}{\partial t}+\frac{\partial[h U c]}{\partial x}+\frac{\partial[h V c]}{\partial y}+\frac{\partial(\omega c)}{\partial \sigma}= \\
& h\left[\frac{\partial}{\partial x}\left(D_{H} \frac{\partial c}{\partial x}\right)+\frac{\partial}{\partial y}\left(D_{H} \frac{\partial c}{\partial y}\right)\right]+\frac{1}{h} \frac{\partial}{\partial \sigma}\left[D_{v} \frac{\partial c}{\partial \sigma}\right]+h S
\end{aligned}
$$

Where $\mathrm{S}$ is indicating source and sink terms per unit area, $\mathrm{D}_{\mathrm{H}}$ and $\mathrm{D}_{\mathrm{V}}$ are horizontal and vertical diffusivity and $\omega$ is the vorticity. Mass concentration and scaled vertical co-ordinate 
are denoted by c and $\sigma$. The Suspended sediment reference concentration was estimated using van Rijn's formula [11]. Equation (9) shows the bed load transport rate formulation [6].

$$
\left|S_{b}\right|=0.006 \rho_{s} w_{s} D_{50}^{(\ell)} M^{0.5} M_{e}^{0.7}
$$

Where $S_{b}$ is bed load transport rate $(\mathrm{kg} / \mathrm{m} / \mathrm{s})$ for median diameter $\mathrm{D}_{50}$, sediment mobility number due to waves and currents $M$ and excess sediment mobility number $M_{e}$. Fall velocity $\mathrm{w}_{\mathrm{s}}$ was also computed using van Rijn equation. Bottom sediment change due to bed load transport is calculated using equation(10).

$$
\Delta_{S E D}^{(m, n)}=\frac{\Delta t f_{\text {MORFAC }}}{A^{(m, n)}}\left(\begin{array}{c}
S_{b, u u}^{(m-1, n)} \Delta y^{(m-1, n)}-S_{b, u u}^{(m, n)} \Delta y^{(m, n)}+ \\
S_{b, v v}^{(m, n-1)} \Delta x^{(m, n-1)}-S_{b, v v}^{(m, n)} \Delta x^{(m, n)}
\end{array}\right)
$$

Here $\mathrm{f}_{\text {MORFAC }}$ is user defined morphological factor, $\mathrm{A}^{(\mathrm{m}, \mathrm{n})}$ is area of computational cell $\left(\mathrm{m}^{2}\right), \mathrm{S}_{\mathrm{b}, \mathrm{uu}}$ and $\mathrm{S}_{\mathrm{b}, \mathrm{vv}}$ are computed bed sediment transport vector, $\Delta \mathrm{x}^{(\mathrm{m}, \mathrm{n})}$ and $\Delta \mathrm{y}^{(\mathrm{m}, \mathrm{n})}$ are cell widths in $\mathrm{x}$ and $\mathrm{y}$ direction and $\Delta \mathrm{t}$ is the time interval used for simulation.

\section{Model Setup}

\subsection{Grid Generation}

In order to continue the simulation a horizontal curvilinear grid is set up which covers the whole modeling area. Delft3D utility RGFGRID has been used to generate grid in Cartesian coordinate system (Fig. 2a). The grid extends from Kalurghat to Khal no 18 which is about $30 \mathrm{~km}$. Grid was refined and finally 368 by 33 grids were taken. Local refinement was done near Sadarghat area in order to better approximate the results of imposed scenario at this location.

The model consists a total of 11744 cells having smallest dimension of about $50 \mathrm{~m}$ by $25 \mathrm{~m}$ at Sadarghat area. Bathymetry data was collected from Chittagong Port

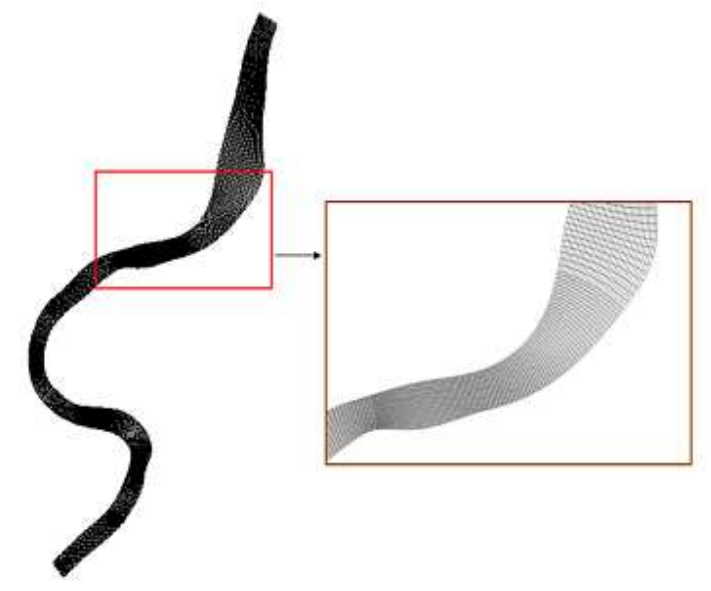

(a)
Authority (CPA) which was in ISLWL(Indian Spring Low Water Level). Delft3D QUICKIN was used to generate bathymetry for the model simulation.

\subsection{Boundary Condition and Time Step}

The model area spans between Kalurghat in the upstream direction and Khal no 18 in the downstream direction. Hourly discharge data was used as the upstream boundary condition and water level data was used as downstream boundary condition. Discharge data for upstream boundary was generated using one dimensional hydrodynamic model HEC-RAS of Halda-Karnafuli river network . Water level data was collected from Chittagong Port Authority (CPA).

Time step is another important consideration for stability and accuracy. Model was run for different type steps and spatially varying Courant number were calculated in order to check the stability. Finally one minute time step has been selected which was found to be sufficient enough for the accuracy and stability of the model.

\subsection{Model Calibration and Verification}

Water level was used as the calibration parameter for the Delft3D model developed. Data was collected from CPA for two stations located at Sadarghat and Khan no-10. Simulated and measured water levels for the month November (post-monsoon condition) and June (monsoon condition) at Khal no-10 were compared and adjusted which was found quite satisfactory (Fig. 3-4). For calibrating the model different values of roughness (Manning's n) have been tested to obtain adequate match with the observed field condition. The whole model area consists of varying roughness values which ranged between $n=0.023$ to $\mathrm{n}=0.028$.

After calibration, the model was validated at Sadarghat for the period 5th November to 16th November 2009 (Fig. 5). It also shows good agreement with the observed data.

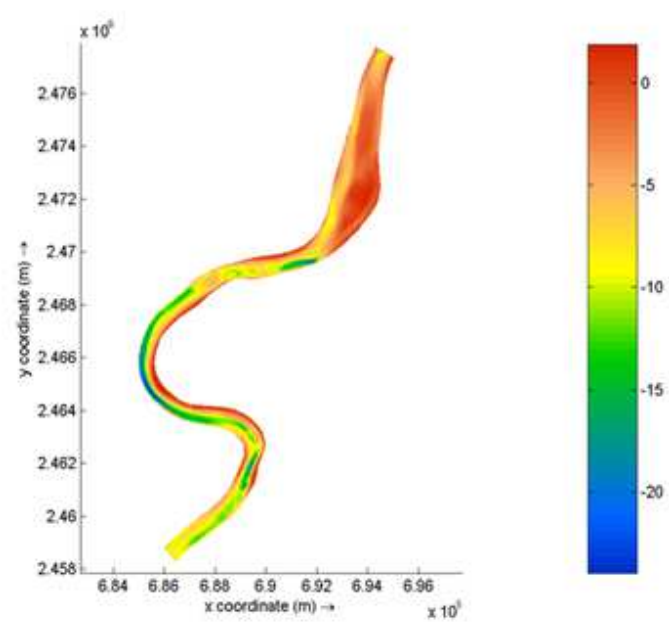

(b)

Figure 2. (a) Curvilinear grids with local refinement (b) Bathymetry of the model area 
In regards to morphological calibration bed levels are computed by adjusting the coefficients and exponents of sediment transport predictor available in the module. However due to lack of measured sediment data the actual compliance of sediment transport capacity has not been achieved. Considerable efforts have been given to calibrate the morphological model by making comparison with the observed bed levels. Bed material sample has been collected and analyzed [4]. The median size of bed material was found to be range from 0.150 to $0.250 \mathrm{~mm}$. The mean value 0.20 $\mathrm{mm}$ has been used as a representative size for morphological computation. Comparison of the computed bed level against the observed one at various section are shown in Fig. 6.

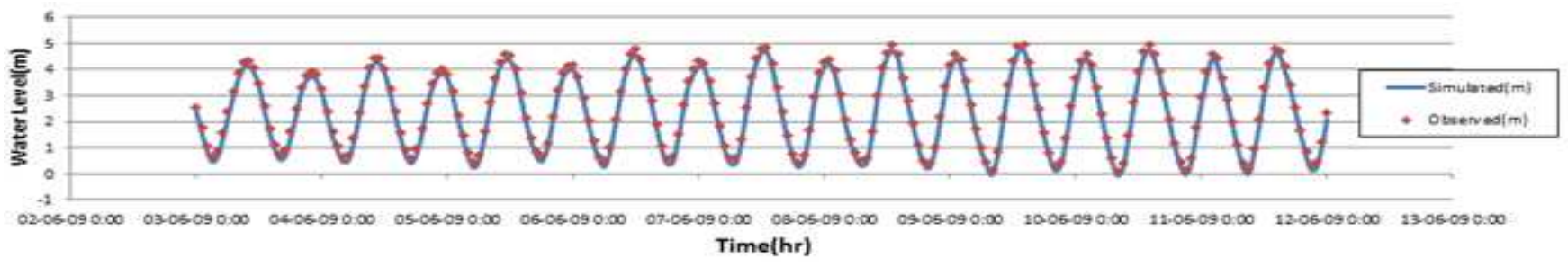

Figure 3. Water Level Calibration at Khal no-10 (3-12 June 2009)

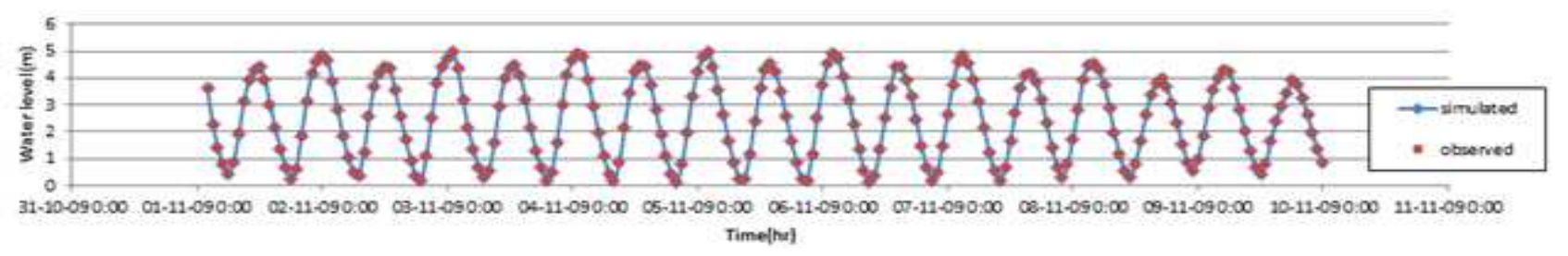

Figure 4. Water Level Calibration at Khal no-10 (1-10 November 2009)

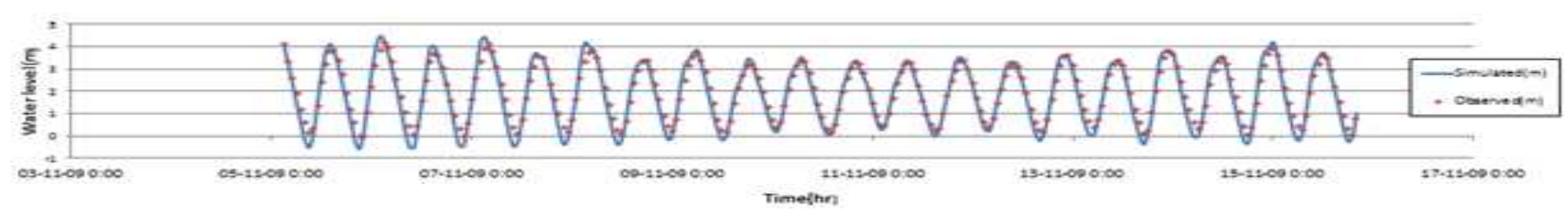

Figure 5. Water Level Validation at Sadarghat (5-16 November 2009)
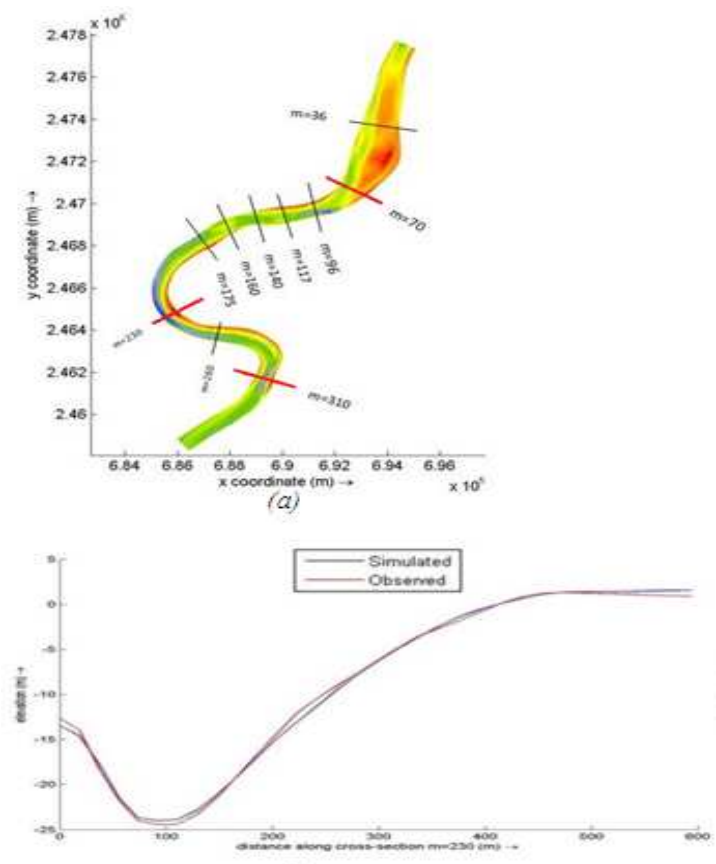

(c)

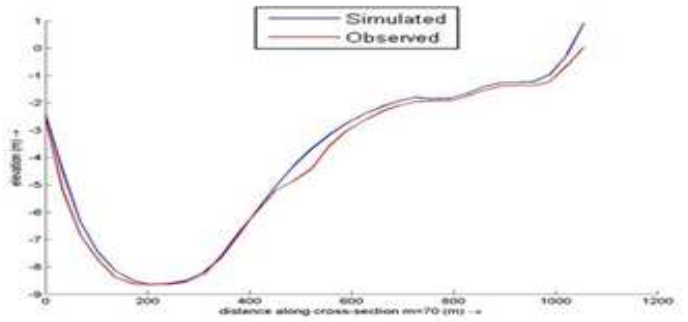

(b)

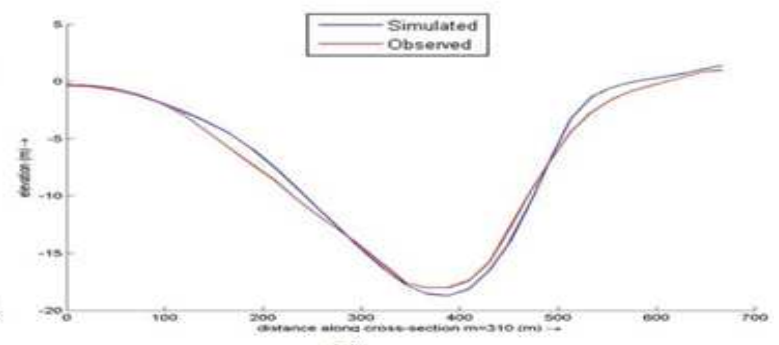

(d)

Figure 6. Bed level comparison between the simulated and observed one (a) Plan view of selected sections (red line) (b) Cross sections $M=70$ ( c) M=230 and $(d) M=310$ 


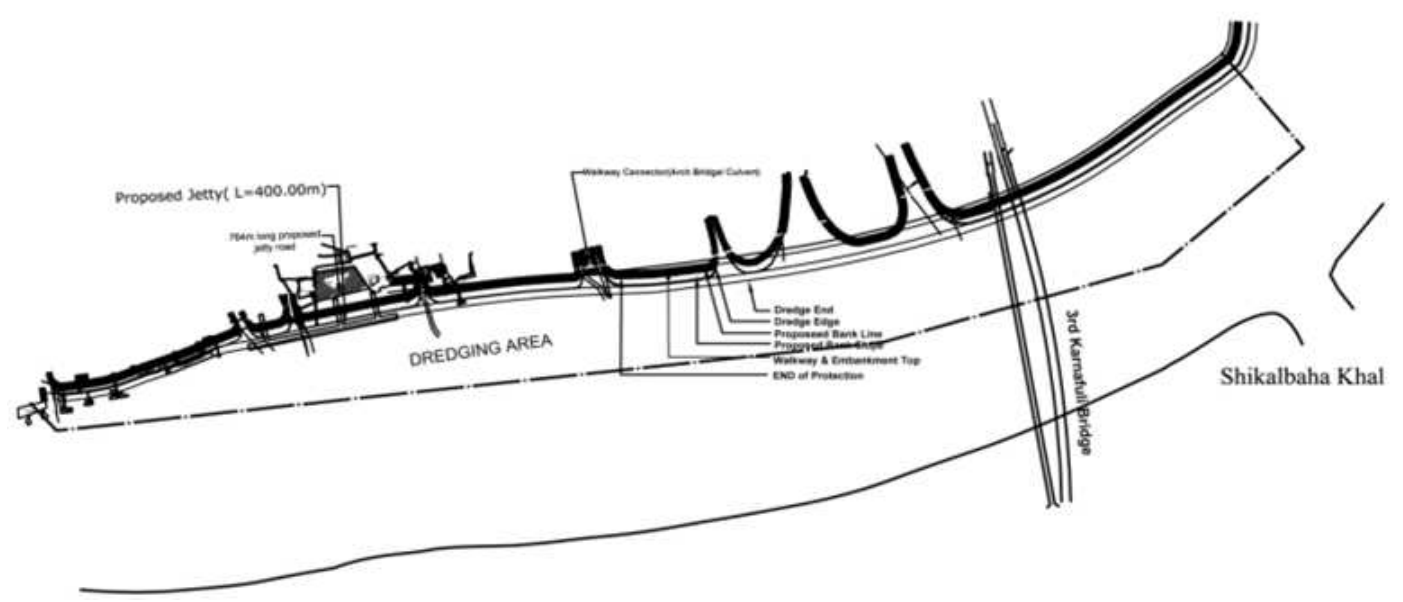

Figure 7. Capital dredging project of Chittagong Port Authority, Bangladesh

\subsection{Capital Dredging and Bank Protection}

\subsubsection{Location of the Intervention (Capital Dredging)}

The Port of Chittagong is located at the north of the Bay of Bengal on the Karnafuli River at a latitude 22018 '30" North and a longitude of $91048^{\prime} 30^{\prime \prime}$ East. The site is located in Chittagong encompassing the right bank of Karnafuli (river) and part of the river Karnafuli from 3rd Karnafuli bridge to Sadarghat area of the Port of Chittagong. Also the project area can be described below.

a) On the North: High Water Line / Existing High

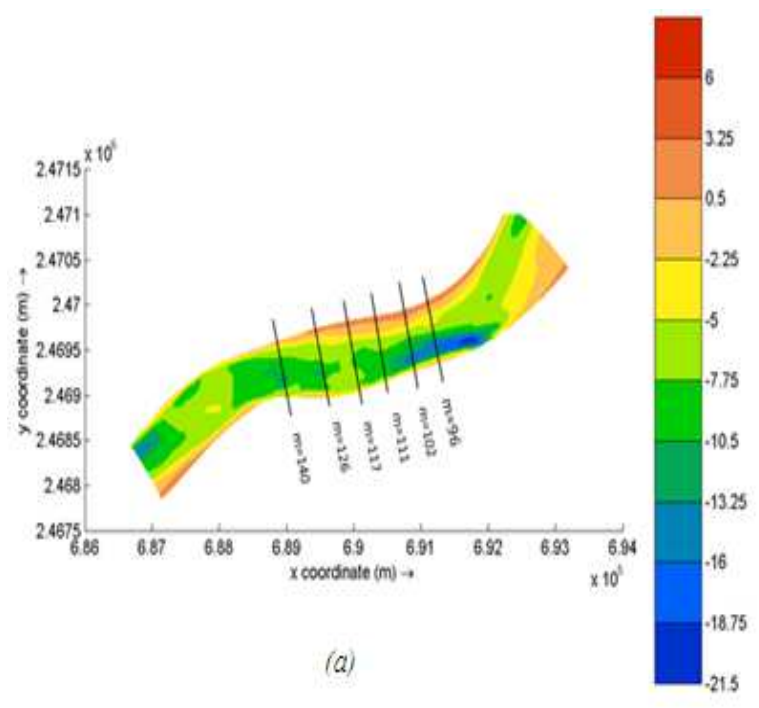

Bank Line

b) On the South: Dredge Limit

c) On the East: $500 \mathrm{~m}$ upstream of 3rd Karnafuli bridge

d) On the West: Approx. $100 \mathrm{~m}$ downstream of Sadarghat Jetty

The dredging site near Sadarghat area is shown in Fig. 7. The area extends from upstream of $3^{\text {rd }}$ Karnafuli bridge to some distance downstream of the proposed jetty.

Figure 8. Bathymetry (a) without and (b) with capital dredging and bank protection

\subsubsection{Application of Capital Dredging and Bank Protection}

Capital dredging project was undertaken at Sadarghat to improve the navigability and flow condition. The developed two dimensional model was further used to assess the effect of capital dredging and bank protection project on the hydrodynamic and morphological properties of Karnafuli River at Sadarghat area. For this purpose the bathymetry of the river has been changed to match the planned section according to the capital dredging project (Fig. 9). Changed cross section includes dredging up to $-4 \mathrm{~m}$ ISLWL and river training works having the peak height $6 \mathrm{~m}$ ISLWL. Each cross section contains a series of steps, those are $-4 \mathrm{~m}, 0 \mathrm{~m}, 6$ $\mathrm{m}$ and lastly some area behind the bank for filling purpose having elevation of about $4 \mathrm{~m}$ ISLWL. Fig. 8 shows the changed cross sections at grid numbers $\mathrm{M}=96,102,111,117$ and 126 (see Fig. 8 for location). Grid numbers of some other features at Sadarghat are, Sikal Baha khal $\mathrm{M}=88$ to 90 ; 3rd Karnafuli Bridge $\mathrm{M}=95$. 

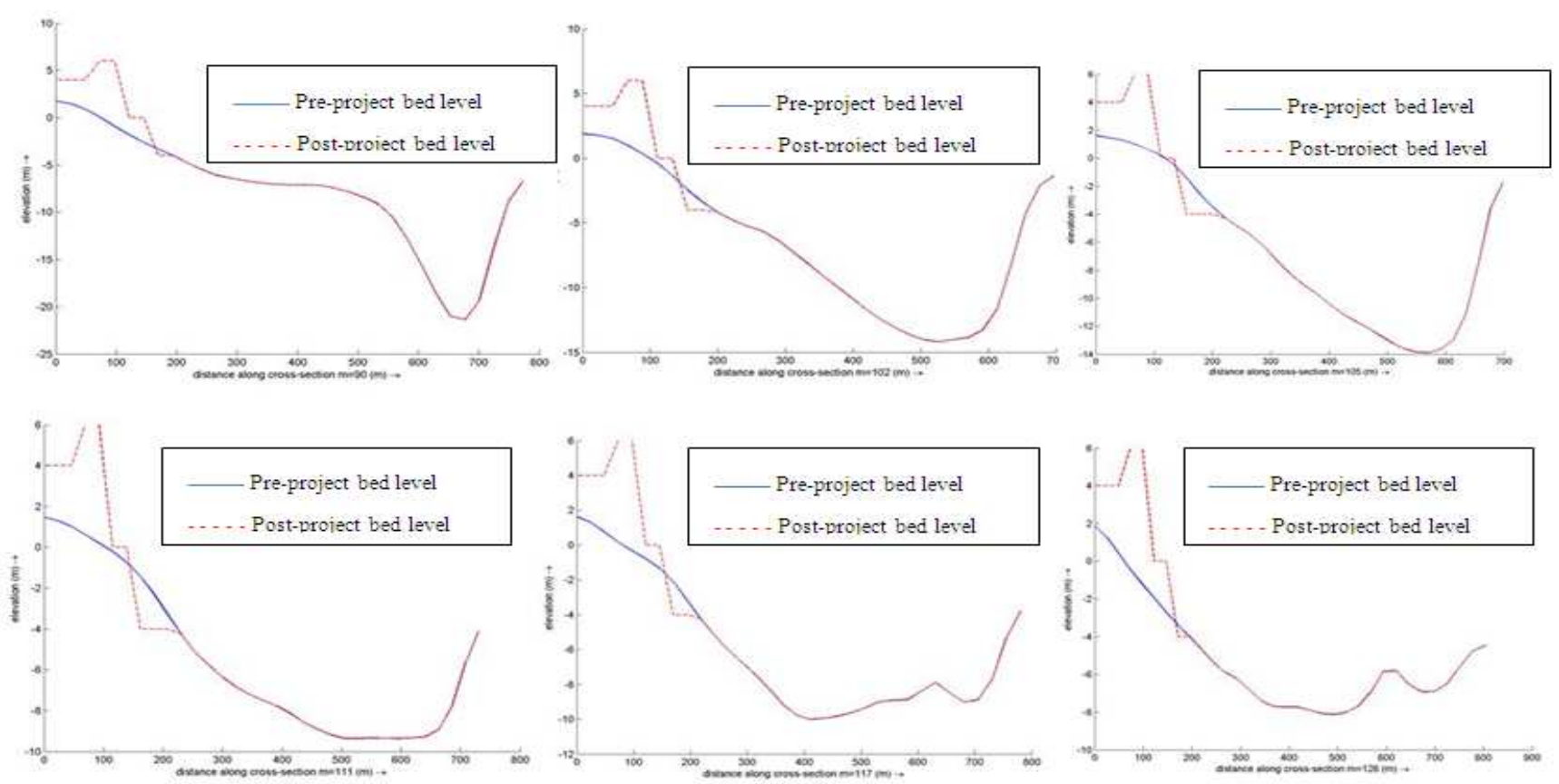

Figure 9. Cross sections of pre- and post project situation

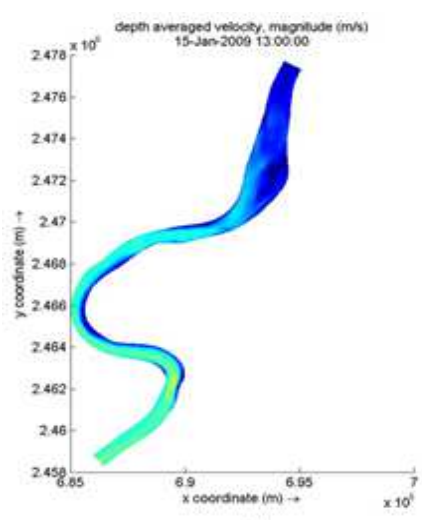

(a)

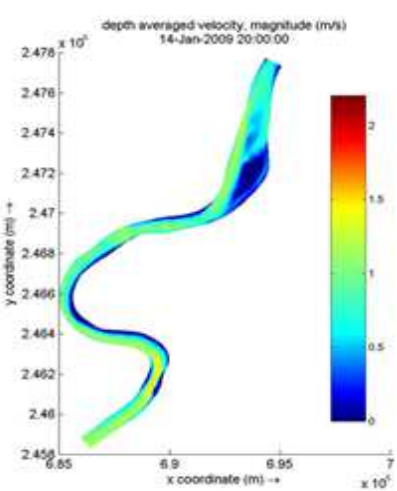

(b)

Figure 10. Velocity variation $(\mathrm{m} / \mathrm{s})$ for spring tide lean period (a) flood (b)ebb

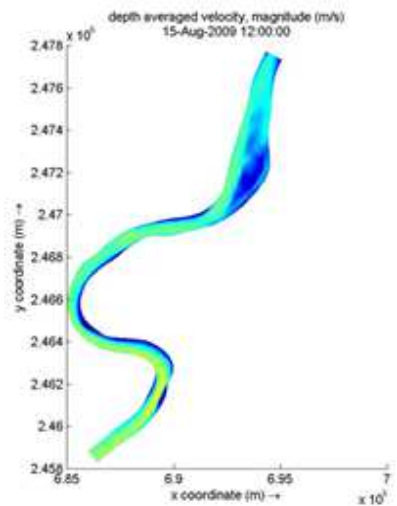

(a)

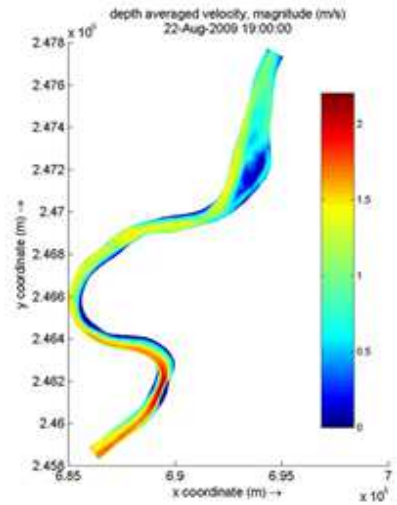

(b)

Figure 11. Velocity variation $(\mathrm{m} / \mathrm{s}$ ) for spring tide monsoon period (a) flood (d) $e b b$

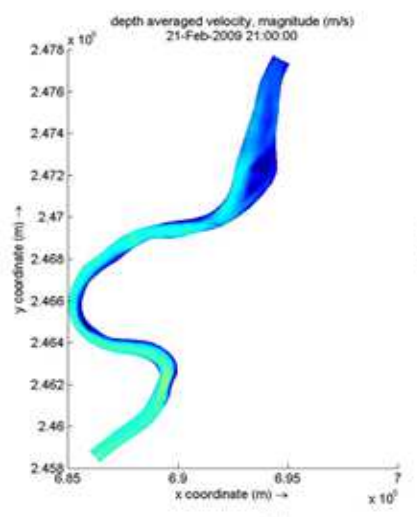

(a)

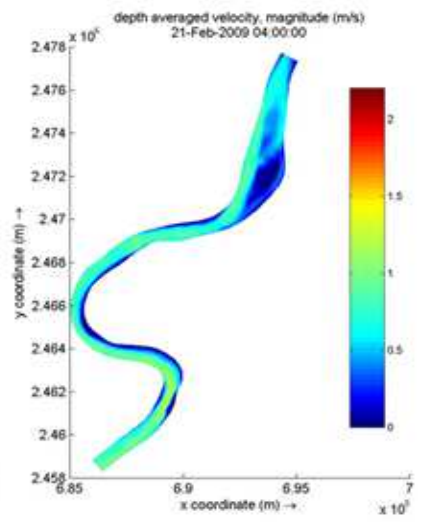

(b)

Figure 12. Velocity variation ( $\mathrm{m} / \mathrm{s}$ ) for neap tide lean period (a) flood (b) $e b b$

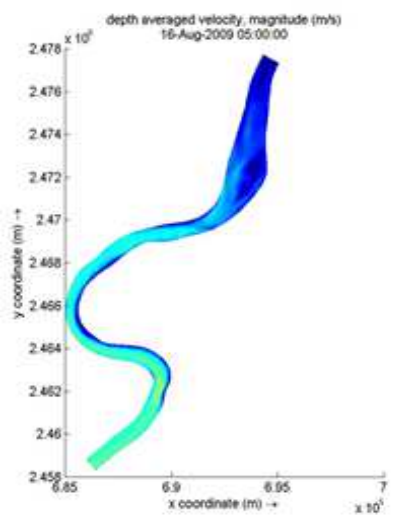

(a)

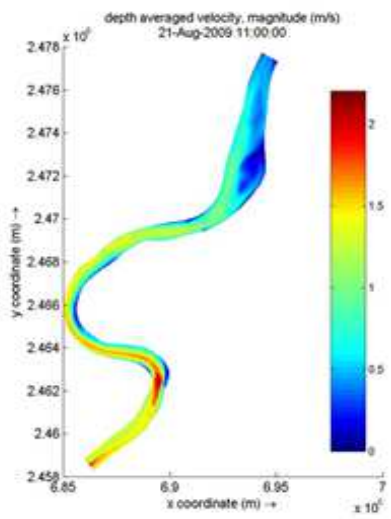

(b)

Figure 13. Velocity variation $(\mathrm{m} / \mathrm{s}$ ) for neap tide monsoon period (a) flood (b) $e b b$ 


\section{Results and Analysis}

\subsection{Variation in Velocity}

The velocity variations at some salient points after model simulation are shown in Fig 10-13 as a visual evidence of the results. However Table 1 and 2 are also shown to interpret extent of such velocity variation under pre-project condition. It is seen that the velocity is higher along the thalweg and near the bends. Four different condition maximum depth-average velocities are shown (Table 1-2) where wet spring period shows maximum velocity of $1.323 \mathrm{~m} / \mathrm{s}$.

Table 1: Maximum longitudinal velocity $(\mathrm{m} / \mathrm{s})$ component during dry (January) season at different points $(M, N)$

\begin{tabular}{cccccc}
\hline Type & $\mathbf{( 9 6 , 2 0 )}$ & $\mathbf{( 1 0 1 , 2 0 )}$ & $\mathbf{( 1 0 5 , 2 0 )}$ & $\mathbf{( 1 1 1 , 2 0 )}$ & $\mathbf{( 1 4 0 , 2 0 )}$ \\
\hline Spring & & & & & \\
Flood & 0.389 & 0.451 & 0.527 & 0.571 & 0.555 \\
Ebb & 0.704 & 0.783 & 0.791 & 0.915 & 0.965 \\
Neap & & & & & \\
Flood & 0.380 & 0.390 & 0.460 & 0.510 & 0.521 \\
Ebb & 0.640 & 0.711 & 0.724 & 0.820 & 0.843 \\
\hline
\end{tabular}

Table 2: Maximum longitudinal velocity $(\mathrm{m} / \mathrm{s})$ component during wet (August) season at different points $(M, N)$

\begin{tabular}{cccccc}
\hline Type & $\mathbf{( 9 6 , 2 0 )}$ & $\mathbf{( 1 0 1 , 2 0 )}$ & $\mathbf{( 1 0 5 , 2 0 )}$ & $\mathbf{( 1 1 1 , 2 0 )}$ & $\mathbf{( 1 4 0 , 2 0 )}$ \\
\hline Spring & & & & & \\
Flood & 0.78 & 0.965 & 1.013 & 1.06 & 1.13 \\
Ebb & 1.055 & 1.132 & 1.157 & 1.262 & 1.323 \\
Neap & & & & & \\
Flood & 0.150 & 0.1 & 0.14 & 0.18 & 0.17 \\
Ebb & 0.723 & 0.785 & 0.803 & 0.872 & 0.921 \\
\hline
\end{tabular}

\subsection{Variation in Sediment Transport}

Similarly sediment transport characteristics of this river is influenced by the tidal effect. It was found that sediment transport rate is higher during wet season compared to the dry season which is due to the increased discharge during wet season. In all conditions the relative magnitude of sediment transport is almost the same. Some portion near Gupta bend is having higher transport rate. This causes higher erosion/deposition in this portion of the river. Very small portion near Arakan Khal is also having relatively high sediment transport. The narrow side channel on the right hand of Bakulia char is also having higher sediment transport, this leads to continuous erosion of the bed in this portion of the river. All other portions of the river are having relatively lower sediment transport with slight higher magnitude along the thalweg.

\subsection{Erosion and Deposition Process}

Sediment transport characteristics of any river are influenced by the tidal effect. Cumulative erosion/deposition throughout the river was calculated using the model Delft3D for one year simulation. Fig. 14-15 showing quarterly cumulative erosion/deposition . It is evident that change in river bathymetry is not significant for one year period and it shows similar type of change at any location. From the result it can been seen that erosion takes place at some places downstream of Kalurghat bridge. Areas around Sadarghat shows alternating pattern of erosion and deposition. Deposition occurs at the mouth of Shikalbaha khal. Just near the Arakan khal the river bed is having relatively higher elevation which is found eroding in nature.

Table 3 shows cumulative erosion/deposition (m) along the centerline for one year period. The rate also varies across each cross section. Along centerline maximum deposition was found $0.75 \mathrm{~m}$ at $26 \mathrm{~km}$ and maximum erosion was found $1.7 \mathrm{~m}$ at $23 \mathrm{~km}$ from Kalurghat station.

Table 3. Cumulative erosion/deposition (m) throughout the river along centerline

\begin{tabular}{cccccc}
\hline Distance $(\mathrm{km})$ & 5 & 10 & 15 & 20 & 25 \\
\hline Erosion/Deposition(m) & -0.04 & -0.76 & -0.12 & -0.25 & +0.26 \\
\hline
\end{tabular}

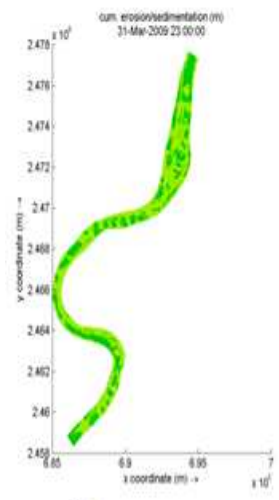

(a)

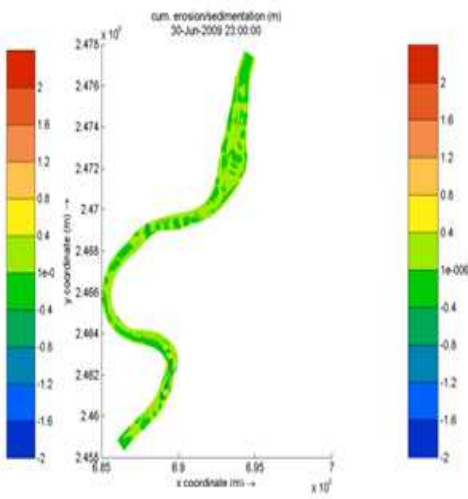

(b)
Figure 14. Cumulative erosion/deposition at the end of (a) March (b) June

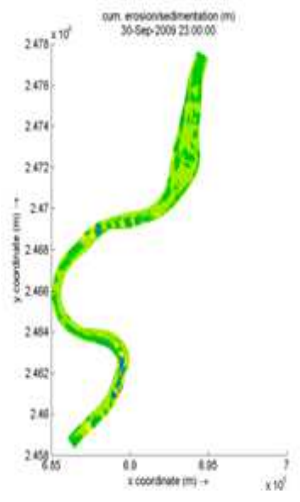

(a)
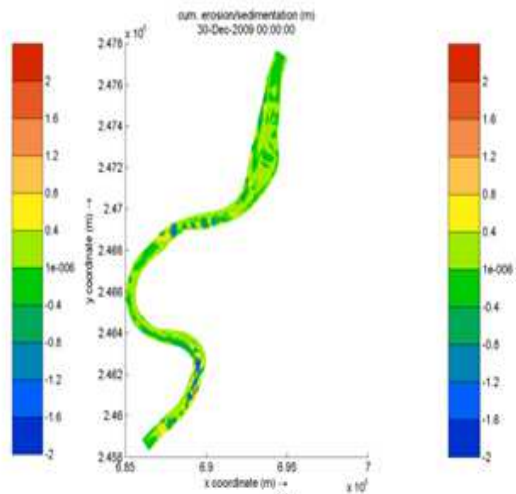

(b)
Figure 15. Cumulative erosion/deposition at the end of (a) September (b) December 
Table 4: Model results showing maximum longitudinal (m component) velocity variation $(\mathrm{m} / \mathrm{s})$ during dry season (January) $[$ Pre $=$ Pre-Project, Post $=$ Post-Project condition]

\begin{tabular}{ccccccccccc}
\hline Type & \multicolumn{2}{c}{$(\mathbf{9 6 , 2 0 )}$} & \multicolumn{2}{c}{$(\mathbf{1 0 1 , 2 0})$} & \multicolumn{2}{c}{$(\mathbf{1 0 5 , 2 0})$} & \multicolumn{2}{c}{$(111,20)$} & \multicolumn{2}{c}{$(\mathbf{1 4 0 , 2 0 )}$} \\
\hline Spring & Pre. & Post. & Pre. & Post. & Pre. & Post. & Pre. & Post. & Pre. & Post. \\
Flood vel. & 0.389 & 0.396 & 0.451 & 0.453 & 0.527 & 0.518 & 0.571 & 0.563 & 0.555 & 0.555 \\
Ebb vel. & 0.704 & 0.7084 & 0.783 & 0.785 & 0.798 & 0.791 & 0.915 & 0.905 & 0.965 & 0.988 \\
Neap & & & & & & & & & & \\
Flood vel. & 0.380 & 0.379 & 0.390 & 0.391 & 0.460 & 0.452 & 0.510 & 0.493 & 0.521 & 0.531 \\
Ebb vel. & 0.640 & 0.645 & 0.711 & 0.715 & 0.724 & 0.721 & 0.820 & 0.812 & 0.843 & 0.860 \\
\hline
\end{tabular}

Table 5: Model results showing maximum longitudinal ( $m$ component) velocity variation $(\mathrm{m} / \mathrm{s})$ during wet season (August) $[$ Pre $=$ Pre-Project, Post= Post-Project condition

\begin{tabular}{|c|c|c|c|c|c|c|c|c|c|c|}
\hline \multirow{2}{*}{$\begin{array}{c}\text { Type } \\
\text { Spring }\end{array}$} & \multicolumn{2}{|c|}{$(96,20)$} & \multicolumn{2}{|c|}{$(101,20)$} & \multicolumn{2}{|c|}{$(105,20)$} & \multicolumn{2}{|c|}{$(111,20)$} & \multicolumn{2}{|c|}{$(140,20)$} \\
\hline & Pre. & Post. & Pre. & Post. & Pre. & Post. & Pre. & Post. & Pre. & Post. \\
\hline Flood vel. & 0.78 & 0.79 & 0.965 & 0.963 & 1.013 & 1 & 1.06 & 1.045 & 1.13 & 1.14 \\
\hline Ebb vel. & 1.055 & 1.072 & 1.132 & 1.140 & 1.157 & 1.157 & 1.262 & 1.263 & 1.323 & 1.347 \\
\hline \multicolumn{11}{|l|}{ Neap } \\
\hline Flood vel. & 0.150 & 0.155 & 0.1 & 0.1 & 0.14 & 0.14 & 0.18 & 0.18 & 0.17 & 0.175 \\
\hline Ebb vel. & 0.723 & 0.727 & 0.785 & 0.789 & 0.803 & 0.801 & 0.872 & 0.874 & 0.921 & 0.937 \\
\hline
\end{tabular}

\subsection{Effect of Capital Dredging and Bank Protection}

\subsubsection{Effect on Velocity}

Magnitude of maximum longitudinal velocity components along the river at different points of the selected reach for pre and post project condition have been shown in Table 4 and Table 5. The selected points cover both upstream and downstream portion of the Dredged area. It is evident that the dredged condition causes an increase in velocity at almost all the upstream and downstream locations near Sadarghat area (dry season and wet season).

\subsubsection{Effect on Erosion/Deposition}

Longitudinal variation of cumulative erosion/deposition within the study area $(\mathrm{M}=67-178)$ along three longitudinal sections $(\mathrm{N}=15,20,25)$ are shown in tabular format. Simulation result shows an increase in erosion or decrease in deposition rate in most of points. Some points showing slight increase in deposition. The overall magnitude of variation is not significant at any of the locations in the observed points.

Table 6: Model results showing cumulative erosion/deposition ( $\mathrm{mm} /$ day) along $N=15,20,25$ after one year period at different distances ( $\mathrm{km}$ ) between $M=67$ to178 [Pre=Pre-project condition, Post $=$ Post-project condition]

\begin{tabular}{|c|c|c|c|c|c|c|}
\hline \multirow[t]{2}{*}{ Distance(km) } & \multicolumn{2}{|c|}{$N=15$} & \multicolumn{2}{|c|}{$\mathrm{N}=\mathbf{2 0}$} & \multicolumn{2}{|c|}{$N=25$} \\
\hline & Pre. & Post. & Pre. & Post. & Pre. & Post. \\
\hline o & 0.183562 & 0.180822 & 0.048493 & 0.048493 & 0.006849 & 0.006849 \\
\hline 1 & 0.410959 & 0.756164 & 0.821918 & 0.841096 & 0.027397 & 0.008219 \\
\hline 2 & 0.013699 & -0.0137 & -0.05479 & -0.06027 & -0.9589 & -0.96164 \\
\hline 3 & 0.712329 & 0.684932 & 0.882192 & 0.90411 & 0.739726 & 0.767123 \\
\hline 4 & 0.136986 & 0.136986 & -1.17808 & -1.23288 & -0.38356 & -0.41096 \\
\hline 5 & -0.21918 & -0.21918 & 0.739726 & 0.739726 & -0.31507 & -0.30137 \\
\hline 6 & 1.156164 & 1.156164 & 1.506849 & 1.452055 & 0.213699 & 0.205479 \\
\hline
\end{tabular}




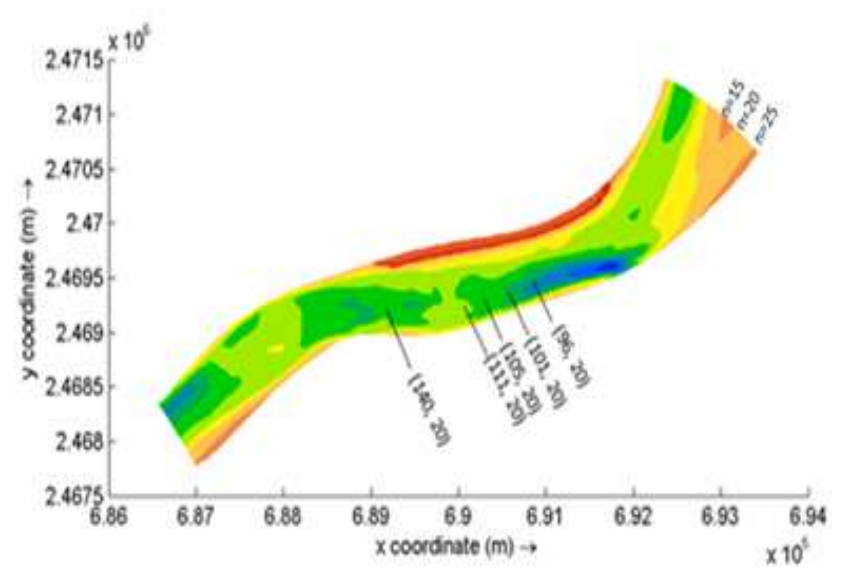

Figure 16. Location of different points at Sadarghat area

\section{Conclusion}

Morphological response of the river due to various development works need proper attention and quantification. The rate of erosion/deposition of this river is always required for estimating the bed level maintenance of the river reach under study. Therefore a two dimensional morphological model has been developed for the Karnafuli river to assess the erosion and deposition pattern due to dredging activities of the port. Considerable efforts have been made to calibrate and validate the model using the available data. Simulated velocity field, shear stress, sediment transport and erosion/deposition of the river reach under study have been generated from the model. In this paper some of typical results are given. Computed results show a variation of maximum depth-averaged velocity between $0.1 \mathrm{~m} / \mathrm{s}$ and $1.323 \mathrm{~m} / \mathrm{s}$ at the vicinity of the port jetty area (Sadarghat) under pre-project condition. However, post project velocity at the point downstream of the dredged area increased $3.33 \%$. The increased velocity indicates a favorable condition for future maintenance dredging requirement. Annual cumulative erosion/ deposition along mid-line of the river was found to vary between $-0.76 \mathrm{~m}$ and $+0.26 \mathrm{~m}$. Erosion/deposition rate of the same area varies between $-69.96 \%$ (erosion) and $+7.1304 \%$ (deposition) due to capital dredging. Overall the model results indicate that considerable improvement in the siltation behavior of the river in the vicinity of Sadarghat jetty area have been achieved under post project condition. As such no significant adverse effect on the river due to capital dredging has been observed from the model results.

\section{Acknowledgements}

Authors are gratefully acknowledging the cooperation rendered by Hydrographic division of Chittagong Port Authority (CPA) for providing the necessary data. Also gratitude renders to Deltares for making Delft3D open source which has been used in this study.

\section{References}

[1] Alam, S. and Matin, M. A. (2012). "Application of Delft3d mathematical model in the river karnafuli for two dimensional simulation." ICACE 2012-Conference Proceeding,CUET, Chittagong. pp:7

[2] Chittagong Port Authority (CPA 2010a), Capital Dredging and Bank Protection with Jetty Facilities; Report on "Mathematical Model Study on the Effect of 3rd Karnafuli Bridge on the Navigability of Karnafuli River within Port Limit.” Dept. of WRE, BRTC, BUET, 2010

[3] Chittagong Port Authority (CPA 2010b), "Mathematical Model study on the Effect of Korean (KEPZ) Project and Karnafuli River- Effect of Construction of a RCC Jetty on the left Bank of Karnafuli in the vicinity of the river." Dept. of WRE, BRTC, BUET, 2010

[4] Chittagong Port Authority (CPA 2010c), Field Survey Report: "Capital dredging and bank protection with jetty facilities from Sadarghat jetty to 3rd Karnafuli bridge", July 2010, pp:32-39

[5] Chittagong Port Authority (CPA 1987), "Mathematical Model Study of the River Karnafuli." Dept. of WRE and IFCDR, BRTC, BUET, 1987

[6] Delft3D-Flow user manual (2011). "Simulation of multi-dimensional hydrodynamic flows and transport phenomena, including sediments." Version 3.15, revision 14499. pp:373,356

[7] DHI, BUET (1990a), "Mathematical Model Study of Pussur-Sibsa River System and Karnafuli River Entrance", Interim Report, Volume 1 and 2

[8] DHI, BUET(1990b), "Mathematical Model Study of Pussur-Sibsa River System and Karnafuli River Entrance", Final Report, ANNEX 1: Collection and Analysis of Data

[9] L.C. van Rijn and D.J.R. Walstra(2003), "Modeling sand transport in Delft3D-Online", WL| Delft Hydraulics, Report, pp:15-17

[10] Schellingerhout, J (2012), "Modeling bio-physical interactions by tube building worm", Bachelor Assignment, Advanced Technology, University of Twente. Pp:17

[11] L.C. van Rijn (1984) "Sediment Transport, Part II; Suspended load transport", Journal of Hydraulic Engineering, vol.110, no.11; pp:1613-1641

[12] Wang, Li ( 2007), "Modelling of Cohesive Sediment Transport in the Maasmond Area", MSc Thesis (WSE-HI.07-18). 